\title{
Biosystematics of Adiantum lunulatum Burm. Complex in India with Special Reference to W. Himalayan Taxa
}

\author{
P. N. Mehra and S. P. Khullar \\ Department of Botany, Panjab University, Chandigarh-160014, India
}

Received February 21, 1976

Adiantum lunulatum Burm. is one of the most common and widely distributed amongst the Indian ferns. In the Himalayan foot-hills, as well as elsewhere, it grows on slopes and walls in moist shady localities upto an altitude of $1,500 \mathrm{~m}$. In the earlier literature on Indian ferns it was known as A.philippense L. Verma (1962) advocated the adoption of the name $A$. lunulatum over $A$. philippense instead.

Cytology has revealed this fern to be a great species complex in India (refer Table 1; Fig. 1). From the E. Himalayas four types have been reported, viz. diploid sexual, diploid apomict, triploid apomict and tetraploid sexual (Mehra and Verma 1963). From S. India too, such types have also been reported (Abraham et al. 1962, P. Methew in Fabbri 1965). The triploid apomict is the more widespread polyploid type and formerly only this type was recorded from the W. Himalayas (Mehra 1938, 1944). In the present extensive survey of the W. Himalayan population of $A$. lunulatum, besides the triploid apomict a diploid apomict has also been detected. In this communication it is intended to discuss the biosystematics of this complex.

In view of the great cytological variation in this complex a little digression upon the taxonomy of the taxa constituting it is essential.

\section{Taxonomy}

From the E. Himalayas 4 taxa of this complex have been reported: diploid sexual, diploid apomict, triploid apomict and tetraploid sexual. The diploid sexual has been named as a separate species A. teestae by Verma (1964). About the tetraploid and diploid sexual, Mehra and Verma (1963) mention that these two are close to each other. The diploid apomict is also very similar. But the triploid apomict differs in many respects. In veiw of this it is desirable to split the E. Himalayan element into two groups, the 'teestae' group comprising the diploid sexual, diploid apomict and tetraploid sexual (Figs. 6-8) and the 'lunulatum' group consisting of the triploid apomict (Fig. 5). The triploid from the E. Himalayas, inspite of morphological variation, conforms to A. lunulatum Burm. These E. Himalayan samples were compared by Dr. R. E. Holttum (Kew) who expressed the view that these specimens 'come nearest' to Burmann's type. The 'teestae' group is characterised by small herbaceous fronds $(4-18 \mathrm{~cm})$, pinnae small $(0.4-1.0 \times 0.6 \mathrm{~cm})$, basal angle between $90-150^{\circ}$, but never more than $180^{\circ}$ (cf. Verma 1964). The 'lunulatum' group is characterised by larger fronds and pinnae as compared to the 
'teestae' group.

The S. Indian material (=A. philippense: Figs. 2,3$)$ agrees in overall morphology with the triploid lunulatum and hence would come under the 'lunulatum' group. The W. Himalayan samples (Fig. 4) too fall in the 'lunulatum' group. The 'teestae' group appears to be restricted to the E. Himalayas alone.

In view of the great diversity in morphology and also the occurrence of different types within the groups ('lunulatum' and 'teestae'), it is desirable, as stated above, to

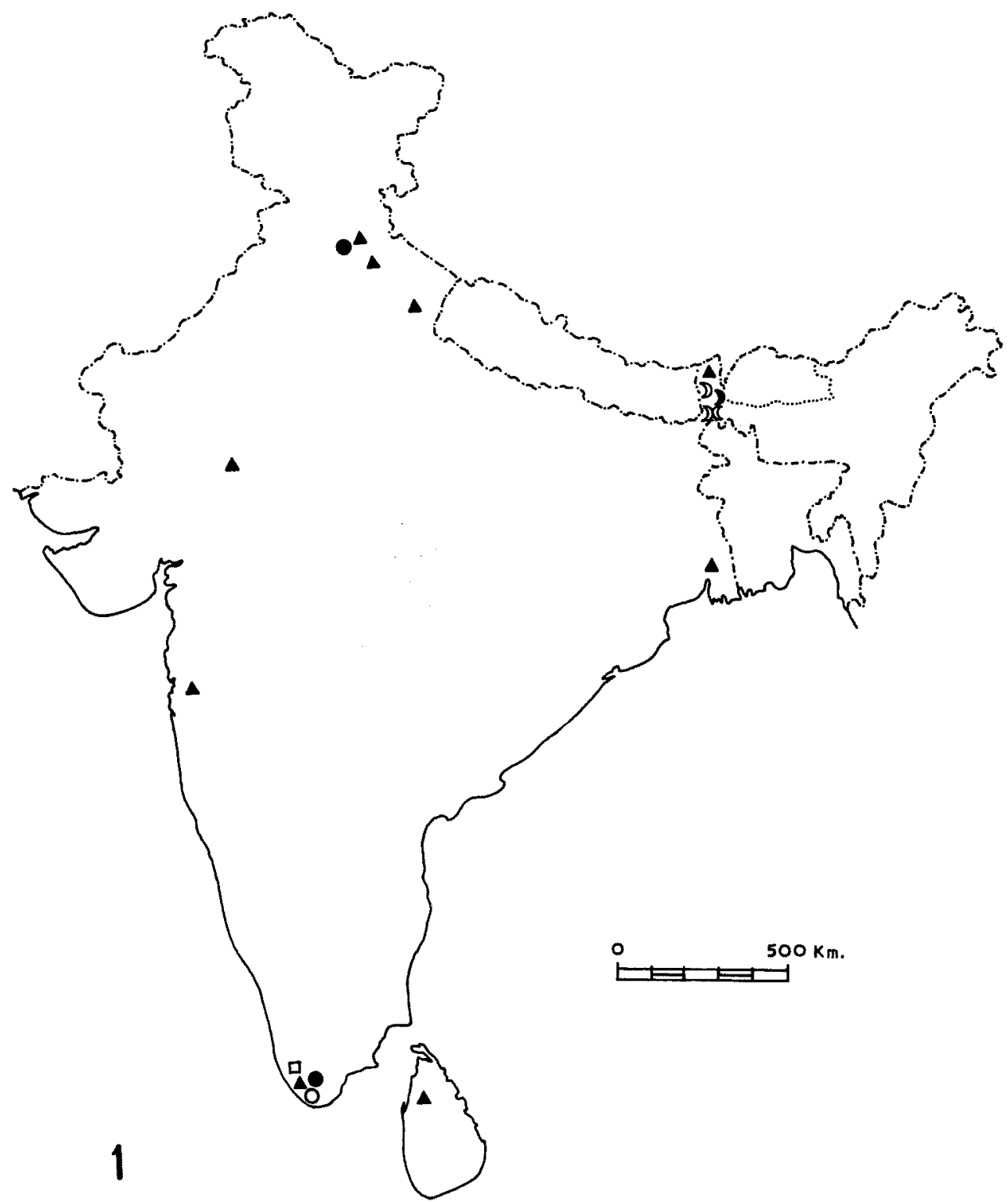

Fig. 1. Map of India showing the distribution of the various polyploid types of Adiantum lunulatum and A. teestae. A. teestae: $)-2 \times S,)-2 \times A, ~)(-4 \times S . \quad A$. lunulatum: $\bigcirc-2 \times S \bullet-2 \times A, \Delta-$ $3 \times A, \square-4 \times S$. S: sexual; A: apomict. 
split A. lunulatum into two different species, $A$. lunulatum Burm. (s.s.) comprising the S. Indian diploid sexual, diploid apomict, tetraploid sexual, the cosmopolitan triploid, as well as the W. Himalayan diploid apomict (Figs. 2-5, 9, 10). The E.

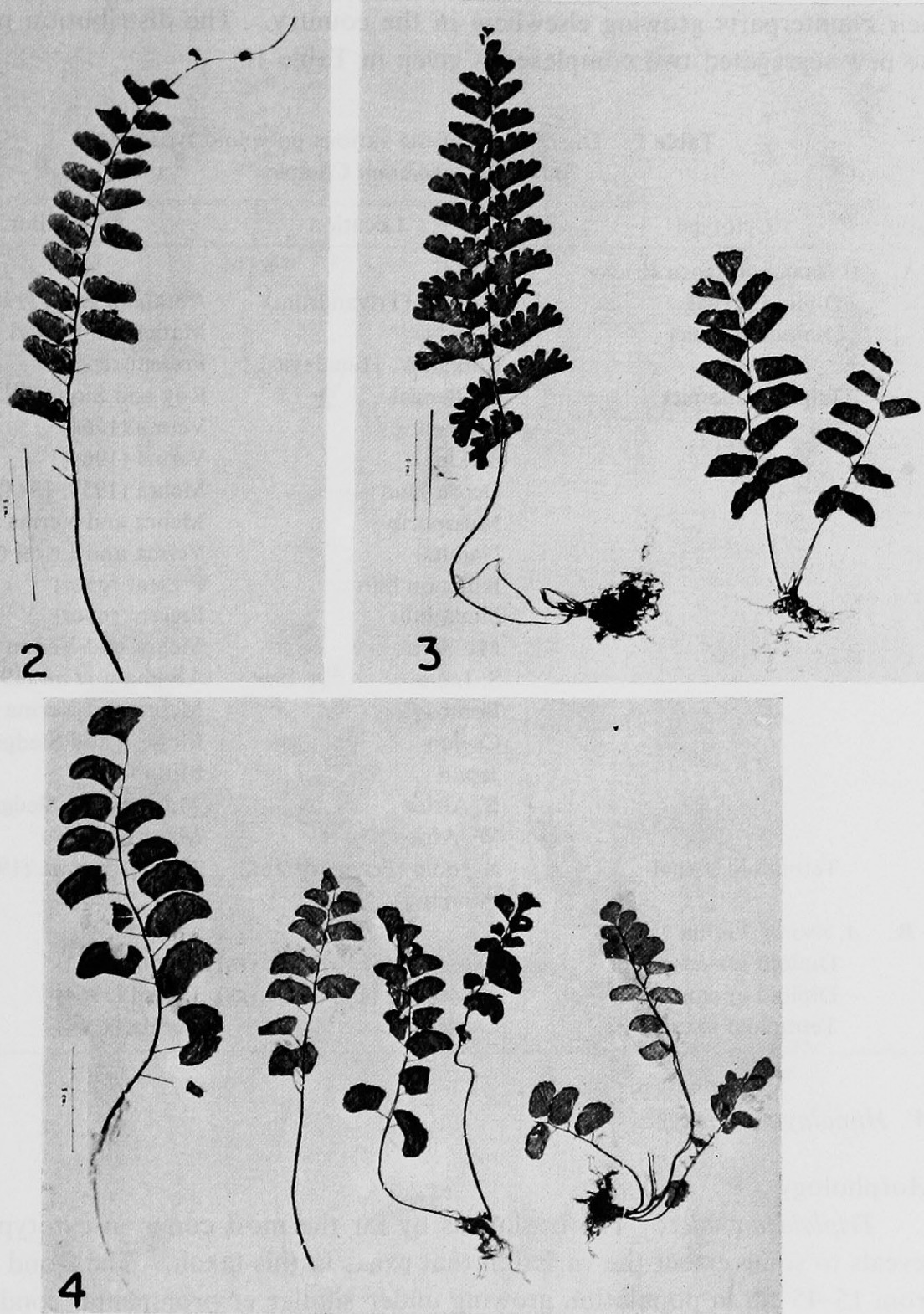

Figs. 2-4. Adiantum lunulatum. 2, diploid sexual (S. India). 3, tetraploid sexual (S. India . 4, diploid apomict (W. Himalayas). All $\times 1 / 4$.

Himalayan diploid sexual, diploid apomict and the tetraploid sexual would comprise the 'teestae' group, characterised by small size of the individuals and pinnae (Figs. $6-8,11$ ). It may, however, be pointed out that these differences (small size, etc.) 
are not due to the environment as the triploid apomict, which also grows in the E. Himalayas under similar environmental conditions, is similar in morphology to the triploid occurring elsewhere in India. It is only the diploid sexual, diploid apomict and tetraploid sexual of the E. Himalayas that are morphologically distinct from their counterparts growing elsewhere in the country. The distribution pattern of the new segregated two complexes is given in Table 1.

Table 1. Distribution of the various polyploid types in Adiantum lunulatum Complex

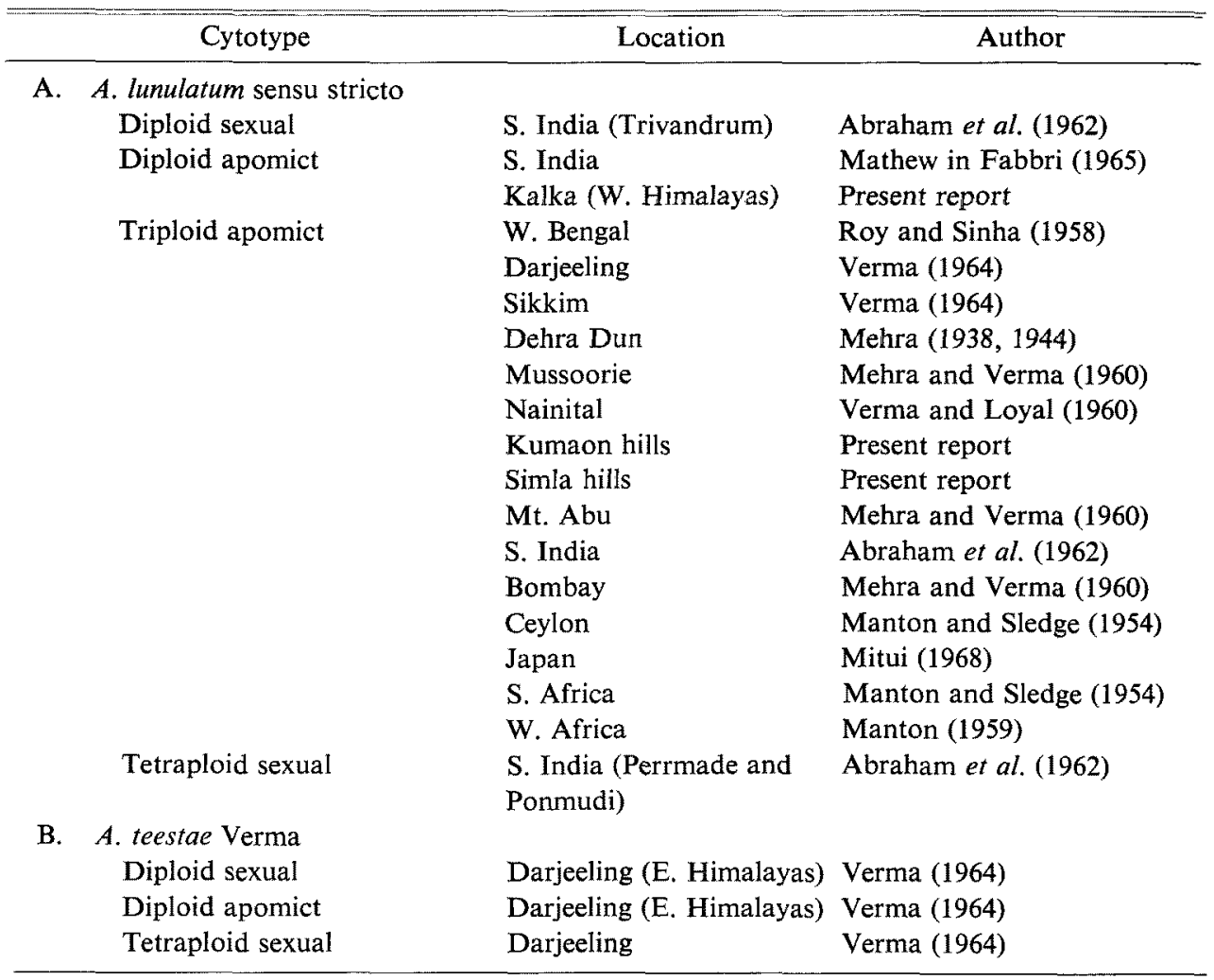

W. Himalayan cytotypes

Morphology

Triploid apomict: The triploid is by far the most common cytotype. Fig. 5 reveals to some extent the variation that exists in this taxon. The frond size varies from $15-45 \mathrm{~cm}$ in population growing under similar environmental conditions. A lot of variation in size and shape of the pinnae also exists. However, there is no correlation between the size of pinnae and that of the plant. Large fronds with small pinnae are not uncommon. Fig. 10 (natural size) depicts the size, shape and lobing patterns that exist in the pinnae. The size varies from $1.0-4.5 \mathrm{~cm}$ long and $0.8-1.5 \mathrm{~cm}$ broad. The pinnae may be lobed, both the large as well as the small ones, or more or less entire. 
Diploid apomict: Like the previous taxon the diploid apomict also shows a fair degree of variation in size of both the frond and the pinnae, as also the shape of the pinnae (Fig. $9 \mathrm{~b}, \mathrm{c}$ ). The frond size varies from $15-30 \mathrm{~cm}$. The size of the pinnae is $1.5-3.0 \mathrm{~cm}$ long and $0.8-1.5 \mathrm{~cm}$ broad. The pinnae may be lobed or entire.

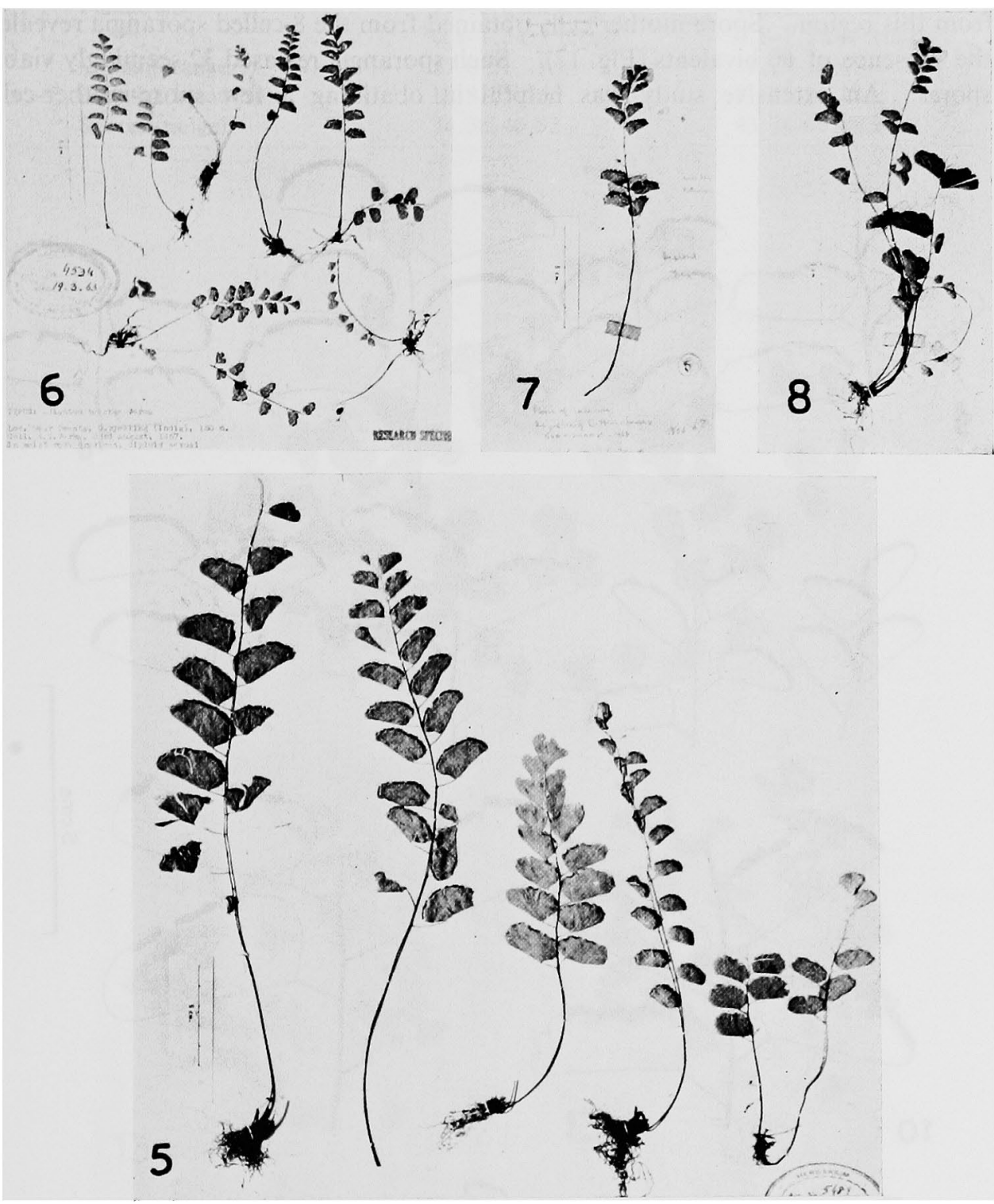

Figs. 5-8. 5, A. lunulatum triploid apomict (W. Himalayas). 6-8, A. teestae. 6, diploid sexual. 7, diploid apomict. 8 , tetraploid sexual. All $\times 1 / 4$.

Table 2 gives a comparison of certain characters of the two cytotypes which reveals a great deal of overall morphological similarity. The size range overlaps in the two, so that without attempting the cytology of the species, it is difficult to distinguish between them. In microscopic characters, however, the diploid apomict 
possesses smaller dimensions of stomata and spores.

\section{Cytology}

Diploid apomict: The diploid apomict in the W. Himalayas has so far been located only at one place, i. e. Kalka. Prior to this only triploids were reported from this region. Spore mother cells obtained from the 8-celled sporangia revealed the presence of 60 bivalents (Fig. 12). Such sporangia released 32 seemingly viable spores. An extensive study was helpful in obatining a few spore-mother-cells
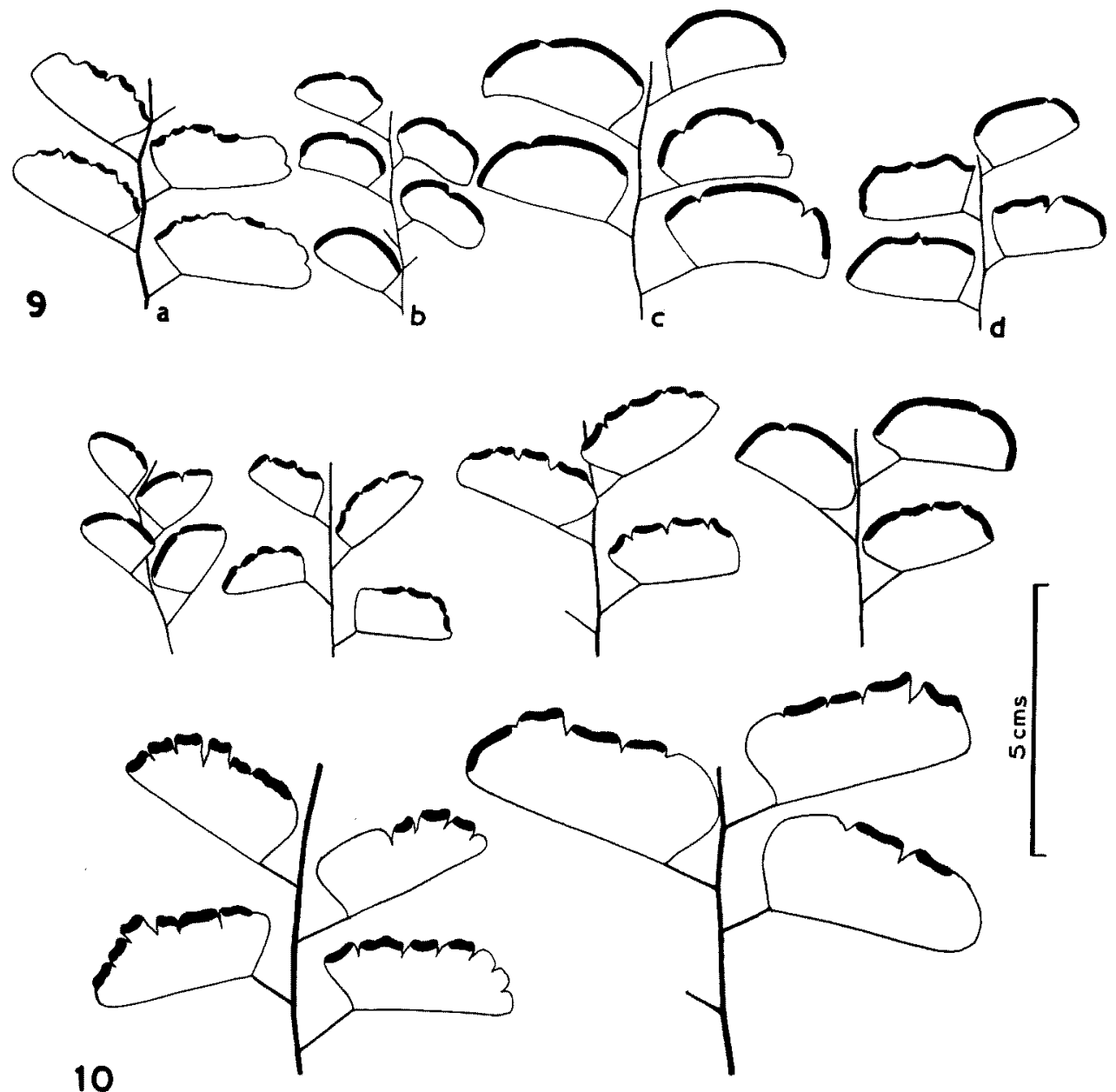

11
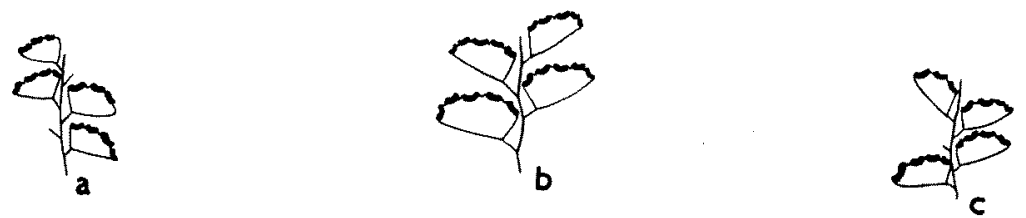

Figs. 9-11. Pinnae. 9, 10, Adiantum lunulatum. 9, (a) diploid sexual, (b, c) diploid apomict, (d) tetraploid sexual. 10, triploid apomict. 11, A. teestae. (a) diploid sexual, (b) diploid apomict, (c) tetraploid sexual. All $\times 1$. 
Table 2. Comparison of diploid apomict and triploid apomict types of Adiantum lunulatum Burm. in the W. Himalayas

\begin{tabular}{lll}
\hline \hline & \multicolumn{1}{c}{ Diploid apomict } & \multicolumn{1}{c}{ Triploid apomict } \\
\hline Frond size & $15-30 \mathrm{~cm}$ & $15-45 \mathrm{~cm}$ \\
Pinnae size & $1.5-3.0 \mathrm{~cm}$ long & $1.0-4.5 \mathrm{~cm}$ long \\
& $0.8-1.5 \mathrm{~cm} \mathrm{broad}$ & $0.8-1.5 \mathrm{~cm} \mathrm{broad}$ \\
Stomata range & $25.0-31.25 \times$ & $31.25-34.47 \times$ \\
(length $\times$ breadth) & $18.8-25.0 \mu$ & $21.87-28.13 \mu$ \\
Spores (range) & $34.38-40.92 \mu$ & $43.74-46.88 \mu$ \\
\hline
\end{tabular}

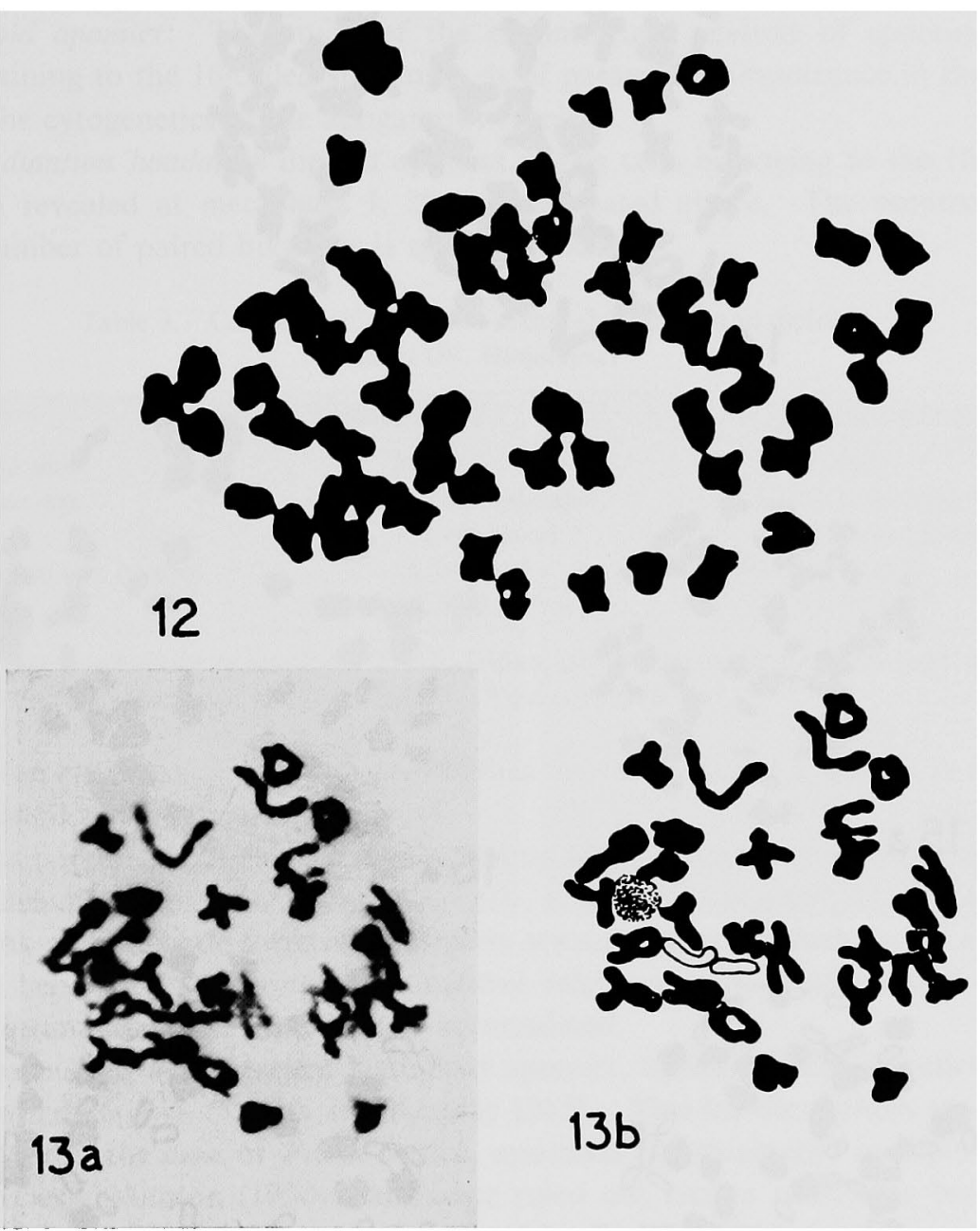

Figo. 12-13. Adiantum lunulatum. 12, diploid apomict ' $n$ ' $=60 . \times 1600 . \quad 13 a$, diakinesis in a spore mother cell from the 16 -celled sporangium in the diploid apomict showing $29_{11}+2_{1}$ (explanatory diagram Fig. 13b). $\times 1600$.

belonging to the 16-celled (normal) sporangia. A study of these revealed 29 II +2 I (Fig. 13a, b).

Triploid apomict: This is the most common cytotype and ranges in its occur- 
rence from the Kumaon hills in the East (in the W. Himalayas) to Simla hills in the West. Dividing spore-mother-cells obtained from the 8-celled sporangia revealed 90 bivalents (Fig. 14), and each such sporangium released 32 spores, pointing to the apogamous nature of the individuals. Mehra (1944) had earlier shown that there is a premeiotic failure of mitosis at 8-celled stage of the sporangium development,

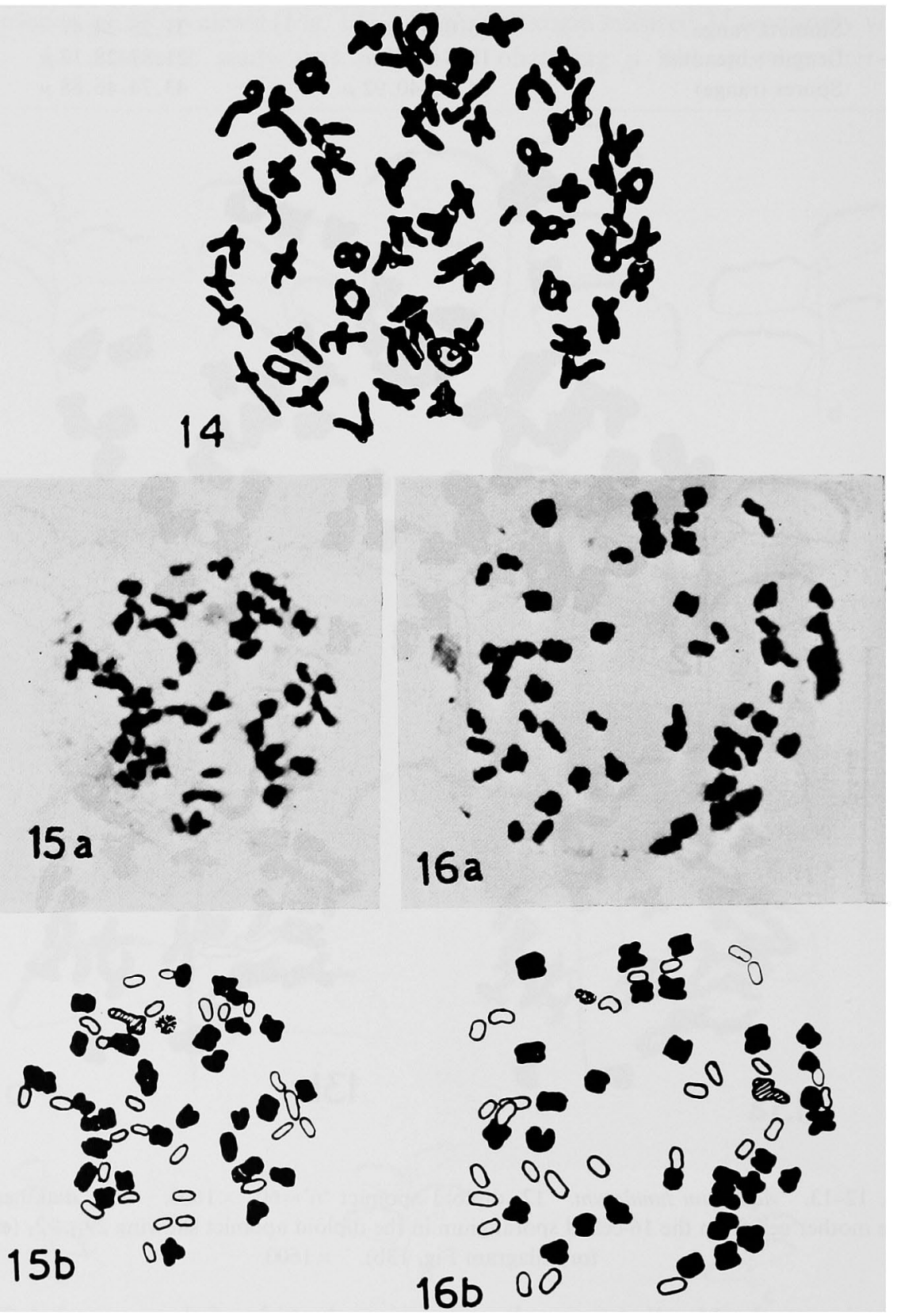

Figs. 14-16. Adiantum lunulatum. 14, triploid apomict ' $n$ ' $=90 . \quad \times 1300 . \quad 15 a-16 a$, diakinesis in"spore mother cells from the 16-celled sporangium in the triploid apomict showing $1_{111}+30_{1 I}+27_{I}$ (explanatory diagrams Figs. 15b and 16b). $\times 1700$. 
thus doubling the chromosome number in the ensuing mother cells and setting a stage for the formation of autobivalents.

A few cells belonging to the 16-celled sporangia were also obtained. An analysis of these revealed the following chromosomal associations:

$1_{\mathrm{III}}+30_{\mathrm{II}}+27_{\mathrm{I}}$ which approximately comes to $\mathrm{X}_{\mathrm{I}}+\mathrm{X}_{\mathrm{II}}$ where $\mathrm{X}=30$ (Figs. $15 \mathrm{a}, \mathrm{b} ; 16 \mathrm{a}, \mathrm{b})$.

Ghatak (1960) reported approximately $30_{\mathrm{II}}+30_{\mathrm{I}}$ in the 16 -celled sporangia, and the same has been corroborated by the investigations of Roy and Sinha (1961).

Cytogenetics

Diploid apomict: The study of the chromosome analysis of spore-mothercells pertaining to the 16-celled sporangia, is of paramount importance in throwing light on the cytogenetics of the apogamous species.

In Adiantum lunulatum diploid apomict, a few cells belonging to the 16-celled sporangia revealed at metaphase I, $29_{\mathrm{II}}+2_{\mathrm{I}}$ as stated above. The occurrence of a large number of paired bivalents is quite significant.

Table 3. Comparison of diploid sexual (S. India)* and diploid apomict (W. Himalayas)

\begin{tabular}{lll}
\hline & Diploid sexual & \multicolumn{1}{c}{ Diploid apomict } \\
\hline Frond size & $30 \mathrm{~cm}$ & $15-30 \mathrm{~cm}$ \\
Pinnae size & $2.5 \mathrm{~cm}$ long and & $1.0-3.0 \mathrm{~cm}$ long and \\
& $1.3 \mathrm{~cm}$ broad & $0.8-1.5 \mathrm{~cm}$ broad \\
Stomatal size (range) & $26.0-29.25 \times$ & $25.0-31.25 \times$ \\
& $19.50-22.75 \mu$ & $18.81-25.0 \mu$ \\
\hline
\end{tabular}

* Only one frond could be studied. The S. Indian samples were obtained through the kind courtesy of Prof. A. Abraham, Kerala University, Trivandrum (India).

Manton (1950) suggested two possibilities for the origin of apomixis in case of diploid apomict Pteris cretica $\mathbf{L}$.

i) As a hybrid between two related species with somewhat complete homology between chromosomes.

ii) As an apomictic form of a formerly sexual species in which, in the absence of sexual behaviour and consequent natural selection, translocations and effects of chromosomal changes subsequently accumulated.

In the case of Pteris cretica L. diploid apomict, analysis of the 16-celled sporangia revealed $26_{\mathrm{II}}+6_{\mathrm{I}}$ (Verma and Khullar 1965). This led the authors to suggest that possibly in the case of Pteris cretica, apomixis has originated in a previously sexual species. Manton (1950) had earlier ruled out such a possibility because a sexual form of $P$. certica aff., now discovered by Walker (1962) from Ternate, was then not known to exist.

In the present case the situation is not very much different. The large number of paired bivalents show a great deal of similarity of genomes. A diploid sexual of the species (A. lunulatum) occurs in S. India which is very much similar to the diploid apomict of the W. Himalayas (cf. Table 3).

In view of the occurrence of a diploid sexual with similar morphological charac- 
ters as the diploid apomict, supported by evidence provided by the chromosomal analysis, it is inferred that the diploid apomict $A$. lunulatum has arisen from the diploid sexual $A$. lunulatum Burm. It is to be noted that both the diploid sexual and diploid apomict forms occur in S. India. Although so far the diploid sexual has not yet been located in the W. Himalayas, its presence here could be suspected. The genetic set up of the diploid apomict (following Mehra 1961) could be symbolically represented as $\mathrm{AA}^{\prime}$ and the sexual form as $\mathrm{AA}$. $\mathrm{A}^{\prime}$ is formed as a result of some sort of cryptic alteration in A genome.

It may be recalled that in case of $A$. lunulatum (s.s.) a whole series, diploid sexual, diploid apomict, triploid apomict and tetraploid sexual exist, with little external morphological variation (cf. Figs. 2-5, 9-10).

Triploid apomict: Some cells belonging to the 16-celled sporangia in the triploid apomict were also observed. An analysis of these revealed the following chromosomal associations as stated above:

$$
1_{\text {III }}+30_{\text {II }}+27_{\text {I }}
$$

These figures are not much different from what Ghatak (1960) and Roy and Sinha (1961) have stated, i.e. $\left(30_{\mathrm{II}}+30_{\mathrm{I}}\right)$.

The constitution of the triploid could be represented symbolically as $\mathbf{A A}^{\prime} \mathbf{B}$, where the species $B B$ is less closely related to $A^{\prime}{ }^{\prime}$. Normally a condition of $X$ pairs $+X$ univalents $(\mathrm{AAB})$ is supposed to occur when a diploid apomict $(\mathrm{AB})$ or a tetraploid (AABB) has back-crossed with one of its parents (Mehra 1961). But in the present context this cytological condition seems to have resulted when a diploid apomict $\mathrm{AA}^{\prime}$ became hybridised with a different but related species $\mathrm{BB}$ resulting in the triploid with $\mathrm{AA}^{\prime} \mathrm{B}$ genomic constitution. However, the taxon with $\mathrm{BB}$ genome has so far not been located.

\section{Summary}

A diploid apomict, in addition to the already known triploid apomict is described from the W. Himalayas in the widely ranging species Adiantum lunulatum Burm. On the basis of morphological evidence it is suggested that the whole complex be split up into two, viz., A. lunulatum (s.s.) comprising the universally known triploid apomict, the diploid and tetraploid sexual from S. India and the diploid apomict from W. Himalayas and S. India. The other species, A. teestae Verma would comprise of the E. Himalayan diploid sexual and diploid apomict forms together with the tetraploid sexual. Chromosomal associations in the 16spore mother-celled sporangia have been analysed and on this eviednce the origin of the two polyploid types in Adiantum lunulatum is discussed. It is argued that the diploid apomict $A$. lunulatum (sensu stricto) probably originated in a previously sexual taxon. Genetically speaking, the diploid apomict is $\mathrm{AA}^{\prime}$, while the triploid is $\mathrm{AA}^{\prime} \mathrm{B}$ in constitution but still possessing approximately $\mathrm{X}$ pairs $+\mathrm{X}$ univalents.

Acknowledgement

The writers wish to express their sincere thanks to Mr. Gurcharan Singh 
Kochhar for taking the photographs.

\section{Literature cited}

Abraham, A., Ninan, C. A., and Mathew, P. 1962. Studies on the cytology and phylogeny of the Pteridophytes VII. Observations on one hundred species of South Indian ferns. J. Indian Bot. Soc. 41: 339-421.

Fabbri, F. 1965. Secondo Supplemento alle Tavole chromosomiche delle Pteridophyta di Alberto Chiarugi. Caryologia 18: 675-731.

Ghatak, J. 1960. Apogamy in Adiantum philippense L. and its cytology. Proc. Ind. Sci. Congr. Part III: 341-342.

Manton, I. 1950. Problems of Cytology and Evolution in the Pteridophyta. Camb. Univ. Press.

- 1959. Cytological information on the ferns of West Tropical Africa. Appendix: The ferns and fern allies of West Tropical Africa, by Alston, A. H. G., 1959, London 75-81.

- and Sledge, W. A. 1954. Observations on the cytology and taxonomy of the Pteridophytic flora of Ceylon. Phil. Trans. Roy. Soc. (London), Ser. B. 654(238): 127-185.

Mehra, P. N. 1938. Apogamy in Adiantum lunulatum Burm. Part I. (Morphological). Proc. Ind. Acad. Sci. B. 8: 192-201.

- 1944. Cytological investigations of apogamy in Adiantum lunulatum Burm. Proc. Nat. Acad. Sci. 14B: 189.

- 1961. Cytological evolution of ferns with particular reference to Himalayan forms (Presidential Address). Proc. Ind. Sci. Congr. Part. II: 130-153.

- and Verma, S. C. 1960. Cytotaxonomic observations on some W. Himalayan Pteridaceae. Caryologia 13: 619-650.

- and - 1963. Polymorphicity and cytogenetics of Adiantum lunulatum complex. Maheshwari Comm. Vol. J. Ind. Bot. Soc. 42A: 110-121.

Mitui, K. 1968. Chromosomes and speciation in ferns. The Science Report of the Tokyo Kyoiku Daigaku, Sec. B. 13: 285-333.

Roy, R. P. and Sinha, B. M. B. 1958. Somatic studies in the genus Adiantum. Proc. Ind. Sci. Congr. 45: 284.

- and - 1961, Meiotic studies in the genus Adiantum. Caryologia 14: 413-428.

Verma, S. C. 1962. Taxonomic status of Adiantum lunulatum Burm. Nova Hedwigia III: 463-468.

- 1964. Cytotaxonomic investigations on some E. Himalayan Pteroids. Ph. D. thesis, Panjab University, Chandigarh.

- and Khullar, S. P. 1965. Cytogenetics of Pteris cretica L. in W. Himalayas. Ann. Bot. 29: 673-681.

— and Loyal, D. S. 1960. Chromosome counts in some ferns from Nainital. Curr. Sci. 29: 69-70.

Walker T. G. 1962. Cytology and evolution in the fern genus Pteris. Evolution 16: 27-43. 